\title{
Coproducing flood risk management through citizen involvement: insights from cross-country comparison in Europe
}

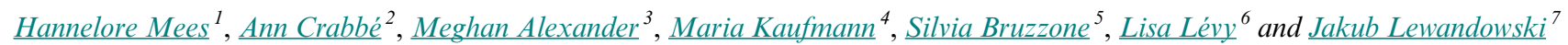

\begin{abstract}
Across Europe, citizens are increasingly expected to participate in the implementation of flood risk management (FRM), by engaging in voluntary-based activities to enhance preparedness, implementing property-level measures, and so forth. Although citizen participation in FRM decision making is widely addressed in academic literature, citizens' involvement in the delivery of FRM measures is comparatively understudied. Drawing from public administration literature, we adopted the notion of "coproduction" as an analytical framework for studying the interaction between citizens and public authorities, from the decision-making process through to the implementation of FRM in practice. We considered to what extent coproduction is evident in selected European Union (EU) member states, drawing from research conducted within the EU project STAR-FLOOD (Strengthening and Redesigning European Flood Risk Practices towards Appropriate and Resilient Flood Risk Governance Arrangements). On the basis of a cross-country comparison between Flanders (Belgium), England (United Kingdom), France, the Netherlands, and Poland, we have highlighted the varied forms of coproduction and reflected on how these have been established within divergent settings. Coproduction is most prominent in discourse and practice in England and is emergent in France and Flanders. By contrast, FRM in the Netherlands and Poland remains almost exclusively reliant on governmental protection measures and thereby consultation-based forms of coproduction. Analysis revealed how these actions are motivated by different underlying rationales, which in turn shape the type of approaches and degree of institutionalization of coproduction. In the Netherlands, coproduction is primarily encouraged to increase societal resilience, whereas public authorities in the other countries also use it to improve cost-efficiency and redistribute responsibilities to its beneficiaries.
\end{abstract}

Key Words: codelivery; coproduction; cross-country comparison; flood risk governance; flood risk responsibilities; legitimacy; public participation; resilience

\section{INTRODUCTION}

In many European countries, a shift can been seen from a flood defense-dominated approach focused on reducing the probability of flooding toward a holistic risk-based approach (Meijerink and Dicke 2008, Nye et al. 2011, Hildén et al. 2012, Kellens et al. 2013). Flood risk management (FRM) encourages the use of measures that aim to reduce both the probability and the consequences of flooding. This approach reflects a strong consensus that it is not practically feasible, financially viable, or sustainable to offer complete protection from flooding. Instead, a diverse ensemble of FRM strategies is advocated to create layers of contingency and address risk at multiple scales (Hegger et al. 2014). In turn, it is argued that this diversification is essential for enhancing societal resilience to flooding. Resilience is a contested concept (Davoudi et al. 2012, MacKinnon and Driscoll Derickson 2013), but it is commonly framed as the capacity to absorb disturbances and reorganize while undergoing change so as to retain essentially the same structure, function, identity, and feedbacks (Walker et al. 2004, Aerts et al. 2008). At the level of the European Union (EU), this approach is endorsed by its call to member states to make arrangements to prevent, protect, and prepare for flooding (European Parliament and Council of the European Union 2007).

In contrast to the flood defense approach, FRM necessitates the involvement of diverse policy domains, such as spatial planning and emergency management, and a broad range of public, private, and civil society actors (Mees et al. 2014). Both at the EU and national levels, calls are increasingly made to involve the public in FRM, e.g., the 1998 Aarhus Convention, the Floods Directive
2007/60/EC, the 2004 Making Space for Water strategy in England, and the 2004 act on civil security in France. In countries such as England, Belgium, and France, policy makers encourage citizens to embrace partial responsibility for FRM, e.g., by improving risk awareness, promoting the uptake of property-level protection (PLP) measures, enhancing preparedness for flooding, and so forth.

We examine how such efforts have emerged in selected EU member states, namely, Flanders (Belgium), England (United Kingdom), France, the Netherlands, and Poland. Flood risk governance in these countries differs widely, having evolved in contrasting socioeconomic, socio-cultural, and socio-political settings. This maximizes opportunities for comparison and critical reflection on how state-citizen interactions manifest in disparate contexts. From a public administration perspective, we examine citizen involvement through the theoretical lens of coproduction, a term traditionally rooted in the study of public services (e.g., Whitaker 1980, Alford 1998, Fotaki 2011). Coproduction is essentially a conceptual umbrella that captures both the involvement of citizens within the decision-making and delivery phases of a public service, in this case FRM.

In contrast to the large body of literature available on public participation in the decision-making process of FRM (e.g., Tippett 2005, Petts 2007, Koontz 2014, OECD 2015), coproduction in the delivery phase is comparatively understudied. Several authors in the United Kingdom have observed a trend toward the devolution of responsibilities to communities at risk of flooding and involving citizens in the implementation of FRM

\footnotetext{
${ }^{1}$ Research Group Environment and Society, University of Antwerp, ${ }^{2}$ Faculty of Social Sciences, Research Group Environment and Society, University of Antwerp, ${ }^{3}$ Flood Hazard Research Centre, Middlesex University, ${ }^{4}$ Institute for Management Research, Radboud University Nijmegen, ${ }^{5}$ CITERES Research Centre, François Rabelais University of Tours, ${ }^{6}$ Institute for Environmental Science, University of Geneva, ${ }^{7}$ Institute for Agricultural and Forest Environment, Polish Academy of Science
} 
measures (e.g., Johnson and Priest 2008, Watson et al. 2009, Nye et al. 2011), but a deeper analysis of the extent to which the trend has developed across the EU and the forces driving it is absent. Addressing this gap, we perform a cross-country comparison of coproduction to examine the following questions:

1. To what extent is coproduction evident in policy discourse and practice in the selected countries? How is this coproduction organized?

2. What are the main rationales for public authorities to (not) involve citizens in the implementation of FRM? How do these underlying rationales influence the divergent approaches toward and institutionalization of coproduction observed in the selected countries?

\section{CONCEPTUAL FRAMEWORK}

\section{New approaches to flood risk management}

The pursuit of FRM can be contextualized within the shift from "government to governance" observed more broadly in society (Ostrom et al. 1961, Peters and Pierre 2001, Termeer et al. 2010). Since the late 1970s, the concept of governance has been associated with nonhierarchical forms of decision making and is used to describe the interaction between state, market, and civil society actors (Driessen et al. 2012). Across a wide range of policies, it is acknowledged that the government is not the only actor steering environmental risk management (Leroy and Arts 2006). Instead, complex relationships have emerged between the state, market, and civil society.

In the field of flood management, the government has long remained the dominant or even single actor in many countries. According to Meijerink and Dicke (2008), protection against flooding was traditionally seen as a pure collective good and thus ideally managed by public authorities. Shifts in the public-private divide, however, have resulted in some cases in which FRM has arguably transitioned into a private good, i.e., benefits are excludable and rivalrous (Meijerink and Dicke 2008, Geaves and Penning-Rowsell 2016). We investigate how the relationship between public authorities and private citizens has evolved and shaped coproduction in the selected countries.

Next to the emergence of a governance approach, the concept of resilience has become of increasing importance for the management of flooding. Resilience includes three core elements, namely, the capacity to resist, to absorb and recover, and to adapt (Alexander et al. 2016a). Among academics and policy makers, disagreement exists on the importance attached to each of these elements. Whereas some consider resistance as a contrasting term to resilience (e.g., de Bruijn 2004), others recognize it as an integral part of resistance (e.g., Bruneau et al. 2003, Davoudi et al. 2012). Within the European research project STAR-FLOOD (Strengthening and Redesigning European Flood Risk Practices towards Appropriate and Resilient Flood Risk Governance Arrangements; http://www.starflood.eu), it was found that all three elements need consideration in a resilient FRM (Hegger et al. 2016).

\section{Coproducing flood risk management through the inclusion of citizens}

Based on the policy cycle (Jann and Wegrich 2007, Crabbé and Leroy 2008), distinct phases can be conceptualized in the FRM process, of which the principal ones are agenda setting; decision making, including the formulation of options and adoption of decisions; and the implementation of decisions. Each of these phases constitutes an "entry point" through which citizens may become involved in FRM. Although the involvement of civil society in FRM decision making has been widely analyzed (e.g., Tippett 2005, Petts 2007, Koontz 2014, OECD 2015), this is less so for citizen engagement in the implementation of FRM, e.g., the installment of PLP measures. Only a limited number of authors in the general public participation literature consider this phase in their analysis (e.g., Macnaghten and Jacobs 1997, White et al. 2010, Nye et al. 2011, OECD 2015).

To address citizen involvement in FRM implementation, we turn to a different strand of literature, namely, to the concept of coproduction of public services introduced in public administration literature. Coproduction is defined by Alford (1998, p. 128) as "the involvement of citizens, clients, consumers, volunteers and/or community organizations in producing public services as well as consuming or otherwise benefiting from them." In contrast to the public participation literature, the concept of coproduction pays specific attention to the delivery phase of public services (Whitaker 1980, Alford 1998, Needham 2008, Fotaki 2011). Some scholars, however, have used it to explain citizen involvement in decision-making processes as well (e.g., Albrechts 2013, Bovaird and Loeffler 2013). For this research, coproduction is conceptualized as an umbrella term that embodies the following dimensions (see Fig. 1):

- Coplanning: participation of citizens in the decision-making process of FRM measures, e.g., development of river basin management plans. In more intensive forms, participation may also inform agenda setting.

- Codelivery: participation of citizens in the implementation of FRM measures, such as flood protection measures at the household level.

- Comprehensive coproduction: participation of citizens in both the agenda setting, decision making, implementation, and evaluation of FRM measures, e.g., the development of an FRM plan may result from the cooperation of citizens and public authorities and therein outline responsibilities for these respective groups.

The first form of coproduction, i.e., coplanning, is already widely addressed in public participation literature on FRM (e.g., Tippett 2005, Petts 2007). Consequently, our scope is limited to the second and third forms. These coproduction forms can vary significantly in terms of goals, content, and so forth. For example, distinctions can be made between inputs delivered by individuals or by groups and whether citizen input is complementary to or substituting for governmental investment (Needham 2008, Bovaird et al. 2015). The requested citizen input can be agreed on in dialogue or imposed one-directionally. According to Needham (2008), collective, dialogical, and positive-sum coproduction is most likely to be beneficial. The input to the coproduction process itself can be variable as well. Citizens can deliver to FRM with knowledge, financial, material, and human resources, i.e., time and effort.

A crucial aspect of coproduction is the existence of an active relationship between public authorities and citizens (Fotaki 
Fig. 1. Forms of coproduction. This figure has been developed by Barbara Tempels and Hannelore Mees (adapted from Mees et al. 2016b). It is based on the phases of the policy cycle and acknowledges the existence of coevolution between these phases and autonomous developments.

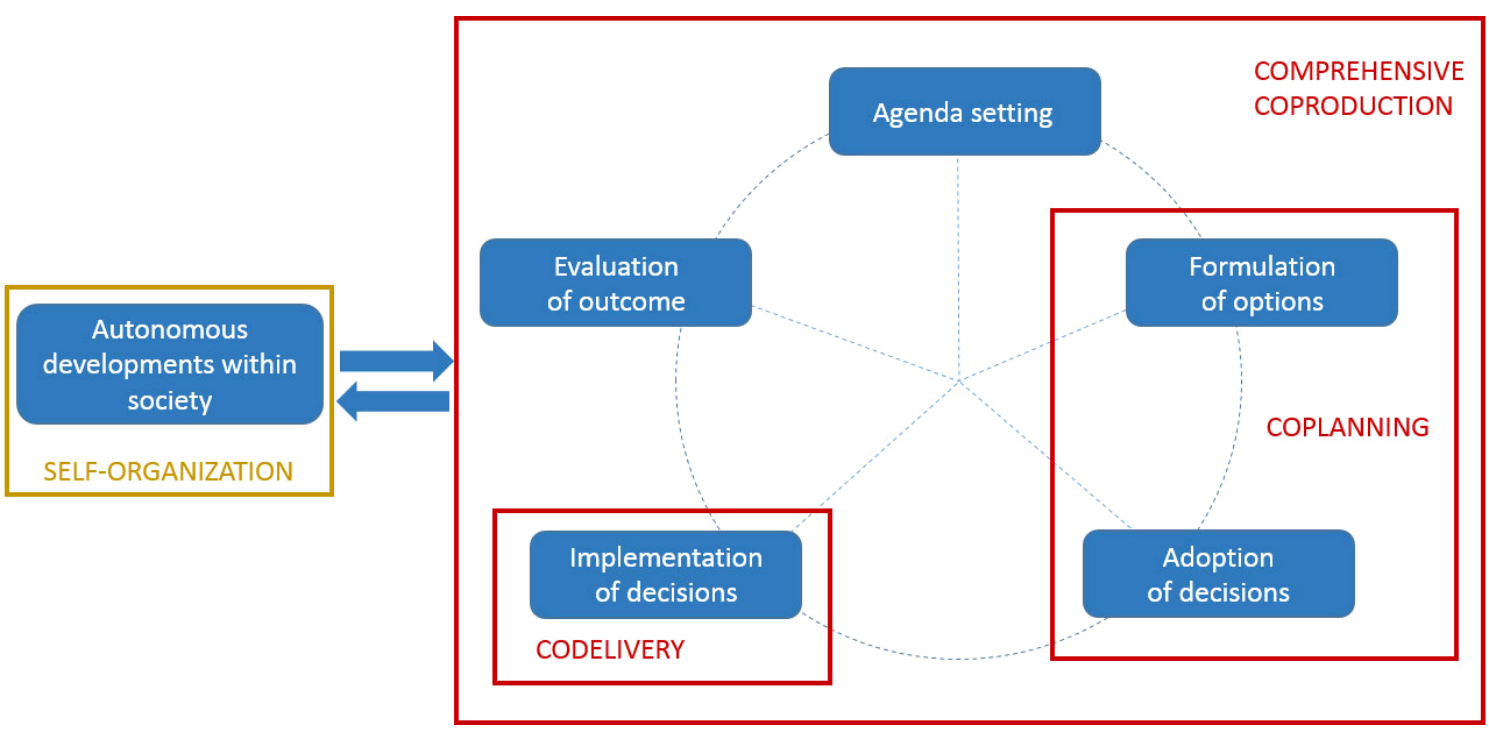

2011). In this way, it distinguishes itself from the concept of selforganization, whereby citizens independently develop and implement FRM measures. Although its definition does not prescribe it, most scholars consider coproduction as initiated by governmental actors (Watson 2014). However, this does not necessarily need to be the case (e.g., Mitlin 2008). Similar to coplanning processes, citizen involvement in the implementation of FRM can include different types of power constellations between state and society, ranging from citizens as exclusive executers of policy decisions to full decision makers in the most advanced cases of comprehensive coproduction (Mitlin 2008, Fotaki 2011). In some cases, coproduction results from a complex interplay between governmental, societal, and market actors. However, we have limited our scope to interactions between governmental actors and (organized) citizens, excluding, for example, the sometimes important role of market actors in flood risk governance, such as insurance companies.

\section{The rationales behind coproduction}

The reasons why governments allow public participation in decision making are discussed in detail by several authors (e.g., Edelenbos and Klijn 2006, Renn 2008, Glucker et al. 2013). For instance, Glucker et al. (2013) distinguish a normative, a substantive, and an instrumental rationale for public participation in the context of environmental impact assessments. The normative rationale aims to empower marginalized individuals and groups and to enhance democratic capacity. In contrast, the substantive rationale refers to the potential of public participation to improve the quality of the decision output. Finally, the instrumental rationale relates to the increase of legitimacy through conflict prevention and resolution.

In public administration literature, the occurrence of coproduction is primarily explained by economic considerations and the failure of a government to (effectively) deliver a service (Parks et al. 1981, Joshi and Moore 2004). The inclusion of citizens in the production of services is thus expected to increase effectiveness and improve allocative efficiency by (1) mobilizing otherwise unavailable community resources, (2) making public services more responsive, and (3) enabling users to shape the outcomes (Bovaird 2007, Needham 2008). In turn, it is argued that this leads to the development of social capital, increased trust in public authorities, and an enhanced action capacity within the community (Ostrom 1996, Mitlin 2008). Some have attributed the interest of public authorities to involve the public in policy delivery to the neoliberalist ideal of "self-reliance," which is particularly evident in resilience agendas in public policy (Davoudi 2012, MacKinnon and Driscoll Derickson 2013). Nye et al. (2011), for instance, observe how responsibilities for FRM are shifting back to the community scale in England in an attempt to enhance self-reliance and empower local communities to become more resilient to flood risk. However, comprehensive studies, e.g., through comparative cross-country research, are noticeably lacking in this field.

\section{METHODOLOGY}

\section{Case selection}

We investigate the form and underlying rationales shaping coproduction in FRM in Flanders (Belgium), England (United Kingdom), France, the Netherlands, and Poland. Although not a country in itself, Flanders is chosen as the unit for analysis because FRM competencies in Belgium are located at the regional level. Similarly, distinct governance arrangements exist in Wales, Scotland, Northern Ireland, and England; hence, England is selected as the analytical unit instead of the United Kingdom. The selected countries are not fully representative of FRM arrangements in Europe and therefore do not allow for general statements applicable to the entire EU. They do, however, reflect divergent forms of flood risk governance and provide exemplars for understanding how different approaches to coproduction in 
Table 1. Flood risks, governance, and economic characteristics of the investigated countries. Figures at country level are included for Flanders (Belgium) and England (United Kingdom) to enable the use of data sets with the same methodology.

\begin{tabular}{|c|c|c|c|c|}
\hline & Flood Risks & Governance Characteristics & $\begin{array}{c}\text { Average } \\
\text { Disposable } \\
\text { Household Income } \\
\text { in Euros, } 2014 \\
(\text { Eurostat } 2016 a, b)\end{array}$ & $\begin{array}{c}\text { GDP per Capita in } \\
\text { Euros, } 2014 \text { (Eurostat } \\
2016 a, b)\end{array}$ \\
\hline England & $\begin{array}{l}\text { Vulnerable to coastal, fluvial, and } \\
\text { pluvial flooding, leading to serious } \\
\text { material damage. }\end{array}$ & $\begin{array}{l}\text { Liberal-pluralist, decentralization } \\
\text { process. }\end{array}$ & 20,584 & 30,400 \\
\hline Flanders & $\begin{array}{l}\text { Small-scale fluvial and pluvial flooding } \\
\text { on a regular basis, causing material } \\
\text { damage. }\end{array}$ & Strong public sector, federal structure. & 21,705 & 33,800 \\
\hline France & $\begin{array}{l}\text { Vulnerable to coastal, pluvial, and } \\
\text { fluvial flooding, leading to casualties } \\
\text { and material damage. }\end{array}$ & $\begin{array}{l}\text { Strong public sector, strong tradition of } \\
\text { centralization. }\end{array}$ & 21,199 & 31,100 \\
\hline Netherlands & $\begin{array}{l}\text { High potential risk of coastal, pluvial, } \\
\text { and fluvial flooding. }\end{array}$ & $\begin{array}{l}\text { Strong public sector, key role for central } \\
\text { government. }\end{array}$ & 20,891 & 37,900 \\
\hline Poland & $\begin{array}{l}\text { Vulnerable to coastal, pluvial, and } \\
\text { fluvial flooding, leading to casualties } \\
\text { and material damage. }\end{array}$ & $\begin{array}{l}\text { Strong public sector, transition from } \\
\text { communism to market-based } \\
\text { democracy. }\end{array}$ & 5336 & 10,500 \\
\hline
\end{tabular}

FRM have emerged within different socio-cultural, socioeconomic, and socio-political settings. Table 1 outlines some key contextual characteristics with potential implications for coproduction policy and practice; these are critically examined in the analysis and interpretation of the research findings.

All the countries investigated are susceptible to flooding, but they display a different flood risk profile. Severe flooding took place in Poland in 2010, in England in 2013-2014 and 2015, and in France in 2015. The largest potential flood hazard exists in the Netherlands, with $21 \%$ of its land below sea level (Van Nes et al. 2001). Because of its strong flood defense infrastructure, however, no significant flooding has taken place since 1995.

In each country, FRM is heavily reliant on public spending and is thus state oriented. This being said, every country has specific general governance characteristics that can be of influence for FRM. English governance has a liberal-pluralist tradition, with an emphasis on a market-based system and individual freedom (van Waarden 1995). In the other countries, generally a more dominant role is attributed to the state. Poland's governance structure has been in transition toward a market-based democracy since 1989. In addition, differences exist in terms of multilevel governance. France and Poland are strongly centralized, whereas England underwent a significant decentralization process. The Netherlands has a decentralized structure but with a key role for the central government. Flanders belongs to a federal country, with strong regional governments.

Finally, differences can be found in terms of economic development. GDP per capita and average disposable household income have been selected as indicators of respectively public and individual spending power. Although most countries in our research have a comparable economic capacity, Poland is rated considerably lower (Eurostat 2016a, b).

\section{Data collection and analysis}

A qualitative analysis of coproduction in FRM is made in the 5 selected countries, thereby observing its development in terms of discourse and practice. The research examined a period of 15 years (2000-2015). We chose 2000 as a starting date because the new millennium appeared to be a starting point for policy initiatives on coproduction in several countries.

Data collection was carried out within the STAR-FLOOD project, funded by the EU's Seventh Framework Programme, which examined the influence of flood risk governance on societal resilience to flooding. From December 2013 to March 2015, between 40 and 70 semistructured interviews were conducted in each country with key actors in FRM, including policy makers and practitioners operating at national and local scales. Interviewees represented a range of FRM activities, including spatial planning, flood defense/mitigation, emergency management, and other preparatory-based activities. A small number of civil society actors were also interviewed, but the results predominantly reflect professionals' perspectives on the subject. The interviews did not exclusively focus on citizen involvement but assessed shifts in flood risk governance in general. Because developments in citizen engagement were regularly mentioned by interviewees, we decided to analyze this more in detail. A nonexhaustive overview of the type of questions asked on the issue can be found in Appendix 1. The interviews were subject to inductive qualitative data analysis, based on iterative, systematic coding to identify key themes.

The information gathered from the interviews has been complemented with in-depth policy and legal analysis of purposively selected documents. These include policy strategies, primary and secondary legislation, parliamentary reports, governmental information brochures and websites, and so forth. In addition, in each country one or more workshops took place in which the results of the STAR-FLOOD project were discussed with relevant governmental and nongovernmental actors. This mixed methods approach supported triangulation of findings and interpretations to enhance the validity of research. Although analysis was performed within country silos, country comparisons were facilitated through cross-country dialogue and critical debate across the research team. 
Table 2. Discourse and practice of coproduction in the investigated countries.

\begin{tabular}{|c|c|c|c|}
\hline & $\begin{array}{l}\text { Discourse on Coproduction in Flood } \\
\text { Risk Policy }\end{array}$ & $\begin{array}{l}\text { Coproduction in Flood Mitigation } \\
\text { Practice }\end{array}$ & $\begin{array}{l}\text { Coproduction in Flood Preparation } \\
\text { Practice }\end{array}$ \\
\hline England & $\begin{array}{l}\text { Discourse on shared flood risk } \\
\text { responsibilities, institutionalized in } \\
\text { Making Space for Water policy vision } \\
\text { (2004) and in National Flood and } \\
\text { Coastal Erosion Risk Management } \\
\text { Strategy (2011). }\end{array}$ & $\begin{array}{l}\text { Pilot funding scheme } 2009-2011 \text { of Defra. } \\
\text { Designated floor heights depending on } \\
\text { location on the floodplain, according to } \\
\text { bylaws or Flood Risk Standing Advice } \\
\text { provided by the Environment Agency since } \\
2006 \text {. } \\
\text { Examples across the country of PLP } \\
\text { measures. }\end{array}$ & $\begin{array}{l}\text { The formation of community flood } \\
\text { action groups since } 2000 \text {. } \\
\text { Voluntary community flood warden } \\
\text { schemes, first described in } 1998 \text { (Bye } \\
\text { and Horner 1998). } \\
\text { National and local awareness-raising } \\
\text { campaigns, such as the ongoing } \\
\text { campaign "Know your flood risk." } \\
\text { Flood Resilience Community } \\
\text { Pathfinder scheme to support } \\
\text { community-based FRM activities } \\
\text { (2012). }\end{array}$ \\
\hline Flanders & $\begin{array}{l}\text { Emergent discourse among public } \\
\text { officials that FRM responsibilities are to } \\
\text { be shared with nongovernmental actors } \\
\text { since 2012-2013. }\end{array}$ & $\begin{array}{l}\text { Pilot project on flood-resilient building } \\
\text { (2014). } \\
\text { PLP measures limited to exceptional cases. }\end{array}$ & $\begin{array}{l}\text { Voluntary emergency team at city level } \\
\text { in small number of cities. } \\
\text { Volunteers in majority of fire brigades. }\end{array}$ \\
\hline France & $\begin{array}{l}\text { Emergent discourse on personal flood } \\
\text { risk responsibility, first institutionalized } \\
\text { in act on civil security (2004): "citizens } \\
\text { are responsible for their own safety." }\end{array}$ & $\begin{array}{l}\text { Subsidies for flood protection measures } \\
\text { through Barnier Fund (2003). } \\
\text { Local programs of vulnerability audits for } \\
\text { buildings. } \\
\text { Limited use of PLP measures. }\end{array}$ & $\begin{array}{l}\text { Obligation on local authorities to } \\
\text { provide information on risk and } \\
\text { appropriate behavior since } 2003 \text {. } \\
\text { Flood warden groups since } 2004 \text {. } \\
\text { Volunteers in civil security. }\end{array}$ \\
\hline Netherlands & $\begin{array}{l}\text { FRM is a statutory governmental } \\
\text { responsibility for in-dike territory. }\end{array}$ & $\begin{array}{l}\text { Pilot projects on flood-proof houses or to } \\
\text { increase the water retention capacity of } \\
\text { neighborhoods. } \\
\text { PLP measures limited to out-dike areas. }\end{array}$ & $\begin{array}{l}\text { Awareness-raising campaigns. } \\
\text { Volunteers in fire brigade, next to } \\
\text { professional fire services. } \\
\text { Dike patrols. }\end{array}$ \\
\hline Poland & $\begin{array}{l}\text { FRM is a statutory governmental } \\
\text { responsibility. }\end{array}$ & $\begin{array}{l}\text { Flood protection at property level is very } \\
\text { rare. }\end{array}$ & $\begin{array}{l}\text { Local citizen initiatives of flood leaders } \\
\text { and flood response coordination since } \\
2010 . \\
\text { Voluntary fire brigades, next to } \\
\text { professional fire services. }\end{array}$ \\
\hline
\end{tabular}

\section{RESULTS}

We provide an overview of how coproduction is pursued in flood risk governance in the selected countries. In general, the involvement of citizens is evident in two distinct areas of FRM. First, there appear to be considerable efforts to involve citizens in flood mitigation by encouraging the uptake of property-level measures to reduce the likelihood and magnitude of flood damage, such as using waterproof interior materials or installing floodgates and air-brick covers. Second, citizens can reduce damage by preparing themselves for a flood in an organizational way, e.g., through the development of community or household flood emergency plans or voluntary-based activities to support institutional responses to flooding. In addition, the uptake of flood insurance can in some cases be part of a coproduced FRM between authorities and citizens, but this falls outside our scope. Table 2 provides an overview of the different forms of coproduction found in the countries investigated. It elaborates both on the discourse articulated in public policy and the measures enacted to bring coproduction into practice.

\section{Coproduction in flood damage mitigation at the household and community scale}

From the countries investigated, the rise of PLP measures is most promoted in English flood risk policy. For example, the National Flood and Coastal Erosion Risk Management Strategy (Defra and EA 2011) places emphasis on empowering and reengaging communities in local risk management. PLP measures are increasingly being incorporated within flood defense projects as part of a multiscale approach, e.g., the River Thames scheme. Moreover, at the national scale, the Department for Environment, Food and Rural Affairs (Defra) provided $£ 5.2$ million in funding between 2009 and 2011 to support a PLP pilot scheme, which led to the installation of measures in 1109 properties (JBA Consulting 2012). This was followed by the launch of the Flood Resilience Community Pathfinder scheme in 2012. As part of this scheme, $£ 5$ million was awarded to local authorities in 13 communities to enhance local responsiveness and ownership of flood risk. This included efforts to increase the uptake of PLP measures, such as floodgates, air bricks, pumps, and so forth, in, for example, Liverpool, West Sussex, and Southampton. Subsequent evaluation of the scheme has highlighted important conditions for success, such as the presence of a community flood action group, but also revealed certain obstacles, such as language barriers, cultural issues, issues of property ownership, and so forth (Twigger-Ross et al. 2015). More broadly, it seems that despite a clear policy vision and desire to increase the uptake of PLP measures, this has been difficult to translate into practice. For instance, between 2008 and 2011 it was reported that only about 400 properties per year installed PLP (ASC 2014). Nonetheless, relative to the other selected countries, England displays the most established forms of coproduction in the context of mitigation initiatives. 
Indeed, in other countries the application of flood-resilient building measures remains marginal. At the opposite end of the spectrum from England, PLP measures are rare and not actively promoted in Poland. In Flanders, this development is still in its infancy. The Flemish government published a brochure on PLP measures in 2011 and carried out a pilot project to investigate the potential of these measures in 2014 . In the coming years, it plans to further develop its policy on the subject, e.g., by providing financial incentives (Vlaamse Milieumaatschappij officials, personal communication). These incentives already exist in France, where since 2003 flood-resilient building measures can be cofunded through the so-called Barnier Fund (Larrue et al. 2016). However, to be entitled to funding, PLP measures must be prescribed in the risk prevention plan, which limits their application in practice substantially. In addition, French local authorities can initiate their own programs to finance vulnerability screenings and/or adaptive measures.

FRM in the Netherlands makes a distinction between "in-dike" and "out-dike" areas (Kaufmann et al. 2016). About 100,000 Dutch homes are located between dike and water (Rijksoverheid 2012). Their residents have to protect themselves against flooding, which in some cases leads to advanced examples of flood-resilient building, such as stilt housing and floating constructions. However, these remain exceptional cases. The problem of pluvial flooding is slowly starting to receive more attention, according to our interviews and a survey of Wielinga et al. (2015). A number of ad hoc initiatives have emerged that consist of state-citizen cooperation; for example, the project "Rainproof Amsterdam" advises citizens in areas prone to pluvial flooding in Haarlemmermeer and Oosterbeek (Kennisportaal Ruimtelijke Adaptatie 2016). Nevertheless, no widespread application of flood-resilient building can be found, as is the case in England.

\section{Coproduction in flood preparation and response}

The most common forms of coproduction take place when a flood occurs. Throughout the entire history of disaster management, citizens have played a primary role either through selforganization or in coproduction with the government (e.g., Chesney 1986, Helsloot et al. 2007). During the 20th century, emergency management services became more and more professionalized, and in England, category 1 responders nowadays consist exclusively of professionals, although they maintain strong links with the local voluntary sector, such as the British Red Cross. In the other countries, however, volunteers still form an important part of local fire brigades and civil security services. This type of public engagement can be described as "comprehensive coproduction" because citizens are involved not only in the execution of flood risk actions but also in their decision making and daily management.

Citizen engagement in response to flooding plays a particularly prominent role in Polish FRM, where emergency response is heavily supported by volunteer organizations, such as the scouts, Caritas, and Red Cross. Following severe flooding in 2010, a number of nongovernmental organizations (NGOs) in the Mazowsze region formed a federation called Pomocni Mazowszu in 2015. This NGO is responsible for the coordination of volunteering activities during emergencies and is also involved in flood awareness activities, such as educational programs in schools and so forth.
Recently, a new form of citizen engagement in crisis response has been on the rise in several countries, in the form of citizen "flood leaders" (Poland, Belgium) or "flood wardens" (England). Under these programs, interested citizens are registered and trained to assist in the execution and coordination of response activities during emergency events. In England, community flood wardens help to communicate official warning messages to local inhabitants and are actively promoted by the Environment Agency and local authorities. In Poland and Belgium, similar approaches can be found at the local scale in the form of flood leaders, for example, in Wroclaw and Bierun (Poland) and in Merchtem and Londerzeel (Belgium). In France, the 2004 law to reform civil security has enabled municipalities to establish Municipal Civil Protection Reserves (réservés communales de sécurité civile). These essentially constitute citizen volunteers, specifically trained to assist the population during an emergency and to intervene in coordination with the other professionals, such as fire brigade, police, and so forth. In contrast to traditional volunteering in emergency management, the flood leader system requires less intensive and continuous involvement in risk management.

The most advanced examples in our research on coproduction in flood preparation are the "community flood action groups," which are widely established in England. These groups are typically formed by flood-affected citizens, often with the support of a national charity, the National Flood Forum (NFF), local authorities, and/or the Environment Agency. The first group in England is credited to the Bewdley Resident's Flood Committee, which was established following significant flooding in 2000. Today, the NFF counts about 160 affiliated groups in England and Wales (NFF 2016). Although the activities performed by community groups vary, the formation of community flood action plans is a common task. Defra's Flood Resilience Community Pathfinder scheme has provided financial support to some of these groups, but in most cases, they are self-funded and organized through modes of self-governance (Alexander et al. 2016b).

Apart from these more structured, collective forms of coproduction, several public authorities attempt to improve individual responses in case of flooding. In all the countries investigated, systems have been under development to raise citizens' awareness and knowledge of flood risks and stimulate appropriate behavior, e.g., through online risk maps, floodwarning apps, and so forth. In France, an important step has been the 2004 act on the modernization of the civil security. This act stipulates that "citizens are responsible for their own safety" (Assemblée Nationale 2004: article 4). Accordingly, it provides guidelines to municipalities and departmental actors on how to inform the population about existing risks. After initial reluctance, the Xynthia storm in 2010 and a resulting court case encouraged mayors to provide appropriate flood risk information on their territories (Larrue et al. 2016).

\section{RATIONALES AND CONTEXTUAL FACTORS EXPLAINING COPRODUCTION IN FLOOD RISK MANAGEMENT}

In each of the investigated countries, coproduction in FRM has grown in momentum in the past 15 years, albeit to varying degrees and in different forms, as discussed in the previous section. The 
phenomenon is most widespread in the field of emergency management, which has a long tradition of engaging citizens in its activities. By contrast, coproduction in flood damage mitigation is still in its infancy in most of the countries examined. Governmental discourse and practice on coproduction is most developed in England, whereas it is emerging in Flanders and France, and to a lesser extent in the Netherlands, and is absent in Poland. In general, coproduction in flood mitigation is implemented by individuals while being steered by government, i.e., top-down initiated. More comprehensive, collective, and bottom-up forms of coproduction are found in initiatives aimed at enhancing the preparedness of households and communities to flooding, particularly in England, with good practices also evident in Poland and France. Some authors argue that these more comprehensive forms of coproduction result in increased inequalities and raise issues of accountability, as can also be the case with codelivery (e.g., Johnson et al. 2007, Thaler and Priest 2014). We do not declare whether the existing forms of coproduction allow a fruitful and fair participation of citizens. Instead, we seek to explain these differences in the context of the underlying rationales driving coproduction initiatives in these countries, alongside relevant contextual conditions that emerged from our analysis.

Based on the findings of our research, we distinguish rationales aimed at resilience, efficiency, and fairness to explain the drivers behind coproduction in FRM delivery. For each of these, a number of driving and obstructing forces can be defined, which explain the differences between the cases investigated in our research.

\section{The resilience rationale: enhancing societal resilience to flooding at the household and community scale}

By fostering coproduction, public authorities attempt to increase societal resilience. However, it is noteworthy that resilience is framed differently within public policy in the selected countries, reflecting different normative values. In turn, this has implications for how coproduction is established. In England, societal resilience is defined in terms of the capacity to absorb, recover, and adapt; thus, it is accepted that floods cannot be fully prevented (Wiering et al. 2015). Correspondingly, a diverse set of strategies is delivered at multiple scales to address risk in a holistic way (Alexander et al. 2016b). From the interviews conducted with flood risk professionals in England, it is apparent that the household and community scale is seen as fundamental to these efforts.

In contrast, the Dutch conceptualization of resilience is closely aligned to the notion of resistance, i.e., flood prevention (Wiering et al. 2015). This is translated in constitutional law to guarantee flood safety and the presence of statutory safety standards not evident in the other countries. Nevertheless, attempts are made to raise flood awareness among the population through awareness-raising campaigns, and so forth, to foster appropriate behavior in the event of flooding. Actions of coproduction do not substitute for collective flood risk measures but are pursued in addition as a backup system. Also in the other countries, interviewed public officials expect that coproduction will help minimize flood damage and thereby contribute to society's capacity to absorb and recover.
Driving forces

On the basis of document and interview analysis, there is a clear link between the emergence of the resilience discourse in all its nuances and the growing threat posed by climate change. With mounting scientific evidence, there is a growing awareness across countries that flooding is likely to be exacerbated by climatic changes, sea-level rise, and increased urbanization (Kundzewicz et al. 2010). Moreover, the occurrence of significant flood events within the research period, e.g., flooding in the United Kingdom in 2013-2014 and in France in 2015, has inevitably brought this issue to the fore. As a result, there is a growing consensus that fully preventing flooding will not be possible and that additional measures are required, which aim to reduce the consequences rather than the probability of floods.

\section{Obstructing forces}

In Poland, climate change is found not to act as a driving force of FRM, because public officials consider its impact highly uncertain (Matczak et al. 2016). In the other investigated countries, governmental attempts to improve resilience through coproduction are hampered by a lack of flood awareness among the population. In the Netherlands, for instance, the potential impact of a flood could be catastrophic, but the probability is very low because of the country's high collective protection level. Consequently, authorities struggle to stimulate individual preventive behavior, as became clear from our interviews. According to Baan and Klijn (2004), increasing responsibility and preparedness of citizens is only possible when the frequency of flooding is relatively high. In England, where floods occur frequently, there is a general awareness of flood risk; however, citizens do not necessarily associate personally with this risk. Considerable research documents the impact of denial, "othering," and the search for ontological security (e.g., Harries 2008, Alexander 2014).

\section{The efficiency rationale: decreasing the cost of flood risk management}

A second rationale found among interviewed authorities relates to the pursuit of resource efficiency, wherein coproduction is not meant as a complementary measure in addition to collective protection but as a way to reduce the need for (additional) governmental investment. A governmental cost-benefit analysis in Flanders, for example, demonstrated that in some cases it would be cost-beneficial to protect an area through flood mitigation measures at the household instead of collective level (VMM 2014). Also in England and France, cost-efficiency considerations form an important driver of the increased attention to citizen involvement in FRM delivery. By transferring flood risk responsibilities to private residents, public authorities can either reduce the costs of their policy or get a higher return on investment.

\section{Driving forces}

Coproduction is a governance concept that flourishes in times of austerity. The original insights on coproduction were developed in a context in which U.S. social policy simultaneously faced fiscal cutbacks and an increasing demand for public services (Brudney 1984). It has since been widely applied in development studies to describe cases in which the government fails to sufficiently deliver a certain service (e.g., Ostrom 1990, Joshi and Moore 2004). Examples of bottom-up coproduction found in England and 
Poland fit into this context. The perception that government actions have been insufficient appears to have incited citizens to organize themselves in flood action groups and to appoint flood leaders. In Poland, this is influenced by its relatively low economic capacity (see Methodology). In England, some key actors who were interviewed attributed this to the financial recession and the corresponding "localism" agenda of the English government, which advocates the devolution of responsibility to the local scale, e.g., the Localism Act 2011. In theory, this agenda is branded as a means to increase local stakeholders' decision-making power. However, there is an argument that this was prompted by the desire to shift costs and accountability from the central government (Begg et al. 2015). The debate is situated in the context of a neoliberal discourse on self-reliance (MacKinnon and Driscoll Derickson 2013).

From our interviews, it is clear that coproduction in England, Flanders, and France is partially embedded in a governmental discourse on cost-efficient FRM. Alarming prognoses of future flood risks have led to claims by authorities in these countries that they cannot afford the costs of FRM on their own. Instead, increasing pressure is put on the public administration to make use of cost-benefit analysis tools and to search for new (financial) resources to contribute to FRM. Transferring some responsibility to private residents thereby emerges as an attractive option. The economic crisis of 2008 has also been mentioned as a factor that contributed to bringing cost-efficiency concerns to the forefront.

\section{Obstructing forces}

Cost-efficiency is also an important political driver in the Netherlands, but this has not manifested in increased forms of coproduction. Instead, water engineers advocate collective defense infrastructure as the most cost-efficient flood risk measure (Kaufmann et al. 2016). The main reasons for this are the country's hydrophysical context, which has led to high safety standards and the technical, organizational, and cultural path dependency resulting from past infrastructural investments (Wiering et al. 2015).

\section{The fairness rationale: increasing the legitimacy of flood risk management}

In several countries, coproduction is partially steered by the stance that FRM should be a shared responsibility between government and citizens. Exemplary hereof are the statements on citizen empowerment and responsibility in the British Making Space for Water strategy (2004) or the 2004 civil security act in France. Public officials in England, France, and Flanders advocated the "beneficiary pays" principle in our interviews and stated regularly that citizens who choose to settle in flood-prone areas should also participate in reducing the consequences of this decision. In this sense, sharing flood risk responsibilities is in some cases considered to be a way to increase the legitimacy of FRM; it is no longer the taxpayer alone who must invest in the protection of residents settling in flood-prone areas.

\section{Driving and obstructing forces}

The transfer of flood risk responsibilities can be contextualized within a broader ideological shift witnessed in public policy across Europe (Bell and Hindmoor 2009), typified in Giddens's thirdway theory (Rose 2000). According to this ideology, governments must provide good living conditions but only in exchange for a mutual effort by citizens, namely, by building strong communities and responsible citizenship. Despite a strong resemblance in general governance approach, huge differences exist between the investigated countries in terms of state-citizen relationships in FRM. These differences can be attributed to cultural, technical, and organizational path dependencies within the examined flood risk policies (see also Mejierink and Dicke 2008).

Because flood risks in the Netherlands are considered to be a vital threat, they form a central part of the constitutional duty of the state to safeguard the "habitability of the country" (Van Rijswick and Havekes 2012). Interestingly, this responsibility is limited to in-dike areas. Residents located outside dike areas are responsible for their own safety, but this affects only about 100,000 homes (Rijksoverheid 2012). Consequently, collective flood protection is the main driver of discourse, institutions, and practice in Dutch FRM. In Poland, the involvement of private actors was nonexistent during the communist era (Kowalczak et al. 2013), and today flood protection and recovery activities still reside within the competences of the state. Consequently, no incentives are given to inhabitants to contribute to their flood protection.

In contrast, in England there is no statutory right to flood protection, and ultimate responsibility resides with the individual (Alexander et al. 2016b). Therefore, coproduction initiatives are strongly driven by a desire to essentially (re)devolve some responsibility back to the local scale (Johnson and Priest 2008, Penning-Rowsell and Johnson 2015).

The devolution of responsibilities is also apparent in France. In 2004, the reform act on the modernization of civil security defines citizens as "responsible for their own safety." However, in practice it appears legally and culturally difficult for the state, as well as for insurers, to encourage citizens' to embrace responsibility in the event of a disaster. The solidarity principle and the constitutional duty of the state to ensure safety for its citizens remain prominent and conflict with efforts to reshape the statecitizen relationship. Hence, concrete programs to foster coproduction in practice are lagging behind.

In Flanders, flood protection is not prescribed as a governmental responsibility by law but has over time become one in practice (Mees et al. 2016a). Among Flemish government officials, there exists an emergent discourse on enhancing personal responsibilities in FRM, but most policy makers are reluctant to voice this in public because it does not correspond with the dominating viewpoint of residents in flood-prone areas (Mees et al. 2016b).

Fairness is a governance principle that can be approached by a utilitarian or an egalitarian approach. A utilitarian approach considers a policy fair if it generates the largest possible benefits for the whole society. A fair policy in the egalitarian tradition implies equal opportunities for all citizens. Whereas France is still strongly rooted in a legal tradition providing "equal treatment for all" (Rothstein et al. 2013), Johnson et al. (2007) found the efforts of the government of the United Kingdom to stimulate coproduction in FRM were clearly inspired by an utilitarian perspective.

In Table 3, an overview is provided of the different rationales and their driving and obstructing forces, as described previously. In addition, the coproduction trend is facilitated by technical developments. Thanks to improved communication systems, such 
Table 3. Overview of governmental rationales behind coproduction and their driving and obstructing forces.

\begin{tabular}{|c|c|c|c|c|c|c|}
\hline & \multicolumn{2}{|c|}{ Resilience Rationale } & \multicolumn{2}{|c|}{ Efficiency Rationale } & \multicolumn{2}{|c|}{ Fairness Rationale } \\
\hline & Driving Forces & Obstructing Forces & Driving Forces & Obstructing Forces & Driving Forces & Obstructing Forces \\
\hline England & $\begin{array}{l}\text { Flood events. } \\
\text { Climate change } \\
\text { projections. }\end{array}$ & & $\begin{array}{l}\text { Cost-efficiency } \\
\text { concerns. }\end{array}$ & & $\begin{array}{l}\text { Government has } \\
\text { no statutory duty } \\
\text { to provide flood } \\
\text { protection. }\end{array}$ & \\
\hline Flanders & $\begin{array}{l}\text { Flood events. } \\
\text { Climate change } \\
\text { projections and } \\
\text { urbanization. }\end{array}$ & & $\begin{array}{l}\text { Cost-efficiency } \\
\text { concerns. }\end{array}$ & & & $\begin{array}{l}\text { No clear division of } \\
\text { responsibility by law. }\end{array}$ \\
\hline France & $\begin{array}{l}\text { Flood events. } \\
\text { Climate change } \\
\text { projections. }\end{array}$ & & $\begin{array}{l}\text { Cost-efficiency } \\
\text { concerns. }\end{array}$ & & & $\begin{array}{l}\text { Gap between formal } \\
\text { and informal division } \\
\text { of responsibility. }\end{array}$ \\
\hline Netherlands & $\begin{array}{l}\text { Climate change } \\
\text { projections and flood } \\
\text { experiences abroad. }\end{array}$ & & & $\begin{array}{c}\text { High safety norms } \\
\text { and past } \\
\text { infrastructural } \\
\text { investments. }\end{array}$ & & $\begin{array}{l}\text { Flood protection as } \\
\text { statutory } \\
\text { responsibility of } \\
\text { government. }\end{array}$ \\
\hline Poland & & $\begin{array}{l}\text { Little attention for } \\
\text { climate change in } \\
\text { policy making. }\end{array}$ & $\begin{array}{l}\text { Insufficient } \\
\text { governmental } \\
\text { resources. }\end{array}$ & & & $\begin{array}{l}\text { Flood protection as } \\
\text { statutory } \\
\text { responsibility of } \\
\text { government. }\end{array}$ \\
\hline
\end{tabular}

as mobile telephones, the Internet, mobile apps, and so forth, it has become much easier to involve citizens in FRM when needed. Moreover, the development of flood-resilient building techniques has created opportunities for flood protection and damage reduction at the household level.

\section{CONCLUSION}

Addressing an existing gap in the literature, we examine the varying degrees and different forms of coproduction in FRM across five European countries. Although coproduction initiatives are most prominent in England, they are emerging in Belgium, France, the Netherlands, and Poland.

The differences in the form and extent to which coproduction is established can be explained by its underlying rationales and different contextual conditions. In the Netherlands, public authorities mainly pursue coproduction, albeit in limited ways, in an effort to enhance societal resilience to flooding. However, given the presence of high statutory safety standards and the state commitment to prevent flooding, coproduction initiatives are considered merely a backup strategy and are less encouraged in practice. Similarly, in Poland, coproduction is in its infancy and is limited by economic constraints and societal attitudes toward the role of the state. The pursuit of resource efficiency is another rationale discerned from this analysis and evident in England, Flanders, and France. In this context, coproduction is seen as a means of sharing the cost burden for FRM across the state and citizens. A final rationale identified relates to different attitudes toward the distribution of FRM responsibilities. For example, whereas the Dutch and Polish legal systems provide for collective protection, this is not the case in England, where there is no statutory right to flood protection. The discussion of responsibilities is attached to perceived ideas of fairness, evident in the principles of solidarity and "beneficiary pays." Moreover, there appears to be a degree of conflict between the vision of public authorities and citizens' expectations that the state should ensure protection from floods. This has been highlighted in our research as a significant barrier to the success of coproduction initiatives.

Further research should investigate the implications of the trends observed. Under which conditions does coproduction manage to fulfill expectations in terms of resilience, efficiency, and fairness, and how can it be pursued without threatening the legitimacy of flood risk policy? The trend toward coproduction in England has been critically addressed by Johnson et al. (2007), Thaler and Priest (2014), Geaves and Penning-Rowsell (2016), and others. According to these authors, the current shift toward private flood risk action increases inequalities within the population and raises questions in terms of accountability. Several scholars also claim that coproduction should be complementary to instead of substitutive for public spending (Ostrom 1996, Osborne and Strokosch 2013), which can be at odds with the efficiency rationale that is underlying trends of coproduction in several countries.

According to several authors (Steinführer et al. 2009, Watson et al. 2009, White et al. 2010), codelivery should be accompanied by enhanced participation opportunities in the decision-making process. This would be an argument for more comprehensive forms of coproduction. It needs to be further investigated whether this has the expected impact on a resilient and legitimate coproduced FRM and what should be the precise roles of each of the parties involved. Hereto, further research should not only address professionals' perspectives, as we have done, but also investigate the prevailing viewpoints on coproduction among the population.

Responses to this article can be read online at: http://www.ecologyandsociety.org/issues/responses. $\mathrm{php} / 8500$ 


\section{Acknowledgments:}

This article has been written in the framework of the STARFLOOD project, which belongs to the European Union's Seventh Framework Programme for Research, Technological Development and Demonstration. This research has received funding from the European Commission under grant agreement no. 308364.

\section{LITERATURE CITED}

Adaptation Sub-Committee (ASC). 2014. Managing climate risks to well-being and the economy. ASC Progress Report 2014. Committee on Climate Change, London, UK.

Aerts, J. C. J. H., W. Botzen, A. van der Veen, J. Krywkow, and S. Werners. 2008. Dealing with uncertainty in flood management through diversification. Ecology and Society 13(1):41. [online] URL: http://www.ecologyandsociety.org/vol13/iss1/art41/

Albrechts, L. 2013. Reframing strategic spatial planning by using a coproduction perspective. Planning Theory 12:46-63. http://dx. doi.org/10.1177/1473095212452722

Alexander, M. 2014. Constructions of flood vulnerability across an etic-emic spectrum. Dissertation. Middlesex University, Flood Hazard Research Centre, London, UK.

Alexander, M., S. Priest, and H. Mees. 2016a. A framework for evaluating flood risk governance. Environmental Science \& Policy 64:38-47. http://doi.org/10.1016/j.envsci.2016.06.004

Alexander, M., S. Priest, A. P. Micou, S. Tapsell, C. Green, D. Parker, and S. Homewood. 2016b. Analysing and evaluating flood risk governance in England - enhancing societal resilience through comprehensive and aligned flood risk governance arrangements. STAR-FLOOD Consortium (Report No. D3.3). Middlesex University, Flood Hazard Research Centre, London, UK.

Alford, J. 1998. A public management road less travelled: clients as co-producers of public services. Australian Journal of Public Administration 57(4):128-137. http://dx.doi.org/10.1111/j.1467-8500.1998. tb01568.x

Assemblée Nationale. Loi $n^{o}$ 2004-811 du 13 aoôt 2004 de modernisation de la sécurité civile. Assemblée Nationale, Paris, France.

Baan, P. J. A., and F. Klijn. 2004. Flood risk perception and implications for flood risk management in the Netherlands. International Journal of River Basin Management 2(2):113-122. http://dx.doi.org/10.1080/15715124.2004.9635226

Begg, C., G. Walker, and C. Kuhlicke. 2015. Localism and flood risk management in England: the creation of new inequalities? Environment and Planning C: Government and Policy 33:685-702. http://dx.doi.org/10.1068/c12216

Bell, S., and A. Hindmoor. 2009. Rethinking governance: the centrality of the state in modern society. Cambridge University Press, Cambridge, UK. http://dx.doi.org/10.1017/cbo9780511814617

Bovaird, T. 2007. Beyond engagement and participation: user and community coproduction of public services. Public Administration Review 67(5):846-860. http://dx.doi.org/10.1111/j.1540-6210.2007.00773. $\underline{x}$
Bovaird, T., and E. Loeffler. 2013. The role of co-production for better health and wellbeing: why we need to change. Pages 20-28 in E. Loeffler, G. Power, T. Bovaird, and F. Hine-Hughes, editors. Co-production of health and wellbeing in Scotland. Governance International, Birmingham, UK.

Bovaird, T., G. G. Van Ryzin, E. Loeffler, and S. Parrado. 2015. Activating citizens to participate in collective co-production of public services. Journal of Social Policy 44(1):1-23. http://doi. org/10.1017/S0047279414000567

Brudney, J. L. 1984. Local Coproduction of services and the analysis of municipal productivity. Urban Affairs Review 19 (4):465-484. http://dx.doi.org/10.1177/004208168401900405

Bruneau, M., S. E. Chang, R. T. Eguchi, G. C. Lee, T. D. O'Rourke, A. M. Reinhorn, M. Shinozuka, K. Tierney, W. A. Wallace, and D. von Winterfeldt. 2003. A framework to quantitatively assess and enhance the seismic resilience of communities. Earthquake Spectra 19(4):733-752. http://dx.doi.org/10.1193/1.1623497

Bye, P. and M. Horner. 1998. Easter floods 1998. Volume 1, report by the independent team to the Board of the Environment Agency. Environment Agency, Bristol, United Kingdom.

Chesney, F. S. 1986. Government prohibitions on volunteer fire fighting in nineteenth-century America: a property rights perspective. Journal of Legal Studies 15:69-92.

Crabbé, A., and P. Leroy. 2008. The handbook of environmental policy evaluation. Earthscan, London, UK.

Davoudi, S., K. Shaw, L. J. Haider, A. E. Quinlan, G. D. Peterson, C. Wilkinson, H. Fünfgeld, D. McEvoy, and L. Porter. 2012. Interface. Applying the resilience perspective to planning: critical thoughts from theory and practice. Planning Theory \& Practice 13(2):299-333.

de Bruijn, K. M. 2004. Resilience indicators for flood risk management systems of lowland rivers. International Journal of River Basin Management 2(3):199-210. http://dx.doi. org/10.1080/15715124.2004.9635232

Department for Environment, Food and Rural Affairs (Defra) and Environment Agency (EA). 2011. Understanding the risks, empowering communities, building resilience: the national flood and coastal erosion risk management strategy for England. The Stationery Office, London, UK. [online] URL: https://www.gov. uk/government/uploads/system/uploads/attachment data/ file/228898/9780108510366.pdf

Driessen, P. P. J., C. Dieperink, F. van Laerhoven, H. A. C. Runhaar, and W. J. V. Vermeulen. 2012. Towards a conceptual framework for the study of shifts in modes of environmental governance - experiences from the Netherlands. Environmental Policy and Governance 22:143-160. http://dx.doi.org/10.1002/ eet. 1580

Edelenbos, J., and E.-H. Klijn. 2006. Managing stakeholder involvement in decision making: a comparative analysis of six interactive processes in the Netherlands. Journal of Public Administration Research and Theory 16(3):417-446. http://dx.doi. org/10.1093/jopart/mui049

European Parliament and Council of the European Union. 2007. Directive 2007/60/EC of the European Parliament and of the 
Council of 23 October 2007 on the assessment and management of flood risks. Official Journal of the European Union 50(L 288):27-34.

Eurostat. 2016a. Database: income and living conditions. European Commission, Brussels, Belgium. [online] URL: $\underline{\text { htp:// }}$ ec.europa.eu/eurostat/web/income-and-living-conditions/data/database

Eurostat. 2016b. Real GDP per capita, growth rate and totals. European Commission, Brussels, Belgium. [online] URL: http:// ec.europa.eu/eurostat $/ \mathrm{tgm} / \mathrm{table} \cdot \mathrm{do} ? \mathrm{tab}=$ table\&init=1\&language $=$ $\underline{\text { en } \& \text { pcode }=\text { tsdec } 100 \& \text { plugin }=1}$

Fotaki, M. 2011. Towards developing new partnerships in public services: users as consumers, citizens and/or co-producers in health and social care in England and Sweden. Public Administration 89(3):933-955. http://dx.doi.org/10.1111/ j.1467-9299.2010.01879.x

Geaves, L. H., and E. C. Penning-Rowsell. 2016. Flood risk management as a public or a private good, and the implications for stakeholder engagement. Environmental Science \& Policy 55:281-291. http://dx.doi.org/10.1016/j.envsci.2015.06.004

Glucker, A. N., P. P. J. Driessen, A. Kolhoff, and H. A. C. Runhaar. 2013. Public participation in environmental impact assessment: why, who and how? Environmental Impact Assessment Review 43:104-111. http://dx.doi.org/10.1016/j.eiar.2013.06.003

Harries, T. 2008. Feeling secure or being secure? Why it can seem better not to protect yourself against a natural hazard. Health, Risk \& Society 10(5):479-490. http://dx.doi.org/10.1080/136985$\underline{70802381162}$

Hegger, D. L. T., P. P. J. Driessen, and M. H. N. Bakker, editors. 2016. A view on more resilient flood risk governance: key conclusions of the STAR-FLOOD project. STAR-FLOOD Consortium, Utrecht, The Netherlands.

Hegger, D. L. T., P. P. J. Driessen, C. Dieperink, M. Wiering, G. T. T. Raadgever, and H. F. M. W. van Rijswick. 2014. Assessing stability and dynamics in flood risk governance: an empirically illustrated research approach. Water Resources Management 28:4127-4142. http://dx.doi.org/10.1007/s11269-014-0732-X

Helsloot, I., E. R. Muller, and J. D. Berghuijs. 2007. Brandweer: studies over organisatie, functioneren en omgeving. Kluwer, Deventer, The Netherlands.

Hildén, M., R. Dankers, T. Kjeldsen, J. Hannaford, C. Kuhlicke, E. Kuusisto, C. Makropoulos, A. te Linde, F. Ludwig, J. Luther, and H. Wolters. 2012. Floods - vulnerability, risks and management. European Topic Centre on Climate Change Impacts, Vulnerability and Adaptation (ETC CCA)/ICM Joint Technical Paper 2/2012. ETC CCA, Bologna, Italy.

Jann, W., and K. Wegrich. 2007. Theories of the policy cycle. Pages 43-62 in F. Fischer, G. J. Miller, and M. S. Sidney, editors. Handbook of public policy analysis. Theory, politics and methods. CRC Press, Boca Raton, Florida, USA.

JBA Consulting. 2012. Evaluation of the Defra property-level flood protection scheme: 25918. Summary Report. Environment Agency, Newcastle upon Tyne, UK. [online] URL: http:// nationalfloodforum.org.uk/wp-content/uploads/Evaluation-of-theDefra-PL-Flood-protection-Scheme-25918.pdf
Johnson, C., E. Penning-Rowsell, and D. Parker. 2007. Natural and imposed injustices: the challenges in implementing 'fair' flood risk management policy in England. Geographical Journal 173 (4):374-390. http://dx.doi.org/10.1111/j.1475-4959.2007.00256.x

Johnson, C. L., and S. J. Priest. 2008. Flood risk management in England: a changing landscape of risk responsibility? International Journal of Water Resources Development 24 (4):513-525. http://dx.doi.org/10.1080/07900620801923146

Joshi, A., and M. Moore. 2004. Institutionalised co-production: unorthodox public service delivery in challenging environments. Journal of Development Studies 40(4):31-49. http://dx.doi. org/10.1080/00220380410001673184

Kaufmann, M., W. J. Van Doorn-Hoekveld, H. K. Gilissen, and H. F. M. W. Van Rijswick. 2016. Drowning in safety. Analysing and evaluating flood risk governance in the Netherlands. Report No. D3.3. STAR-FLOOD Consortium, Utrecht, The Netherlands.

Kellens, W., W. Vanneuville, E. Verfaillie, E. Meire, P. Deckers, and P. De Maeyer. 2013. Flood risk management in Flanders: past developments and future challenges. Water Resources Management 27:3585-3606. http://dx.doi.org/10.1007/s11269-013-0366-4

Kennisportaal Ruimtelijke Adaptatie. 2016. Praktijk. Climate Adaptation Services, Utrecht, The Netherlands. [online] URL: http://www.ruimtelijkeadaptatie.n1/nl/praktijkvoorbeelden-ruimtelijke$\underline{\text { adaptatie }}$

Koontz, T. M. 2014. Social learning in collaborative watershed planning: the importance of process control and efficacy. Journal of Environmental Planning and Management 57(10):1572-1593. http://dx.doi.org/10.1080/09640568.2013.820658

Kowalczak, P., P. Matczak, and L. Slavikova. 2013. Institutional evolution in water management in the Czech Republic and Poland. International Journal of Water Governance 1:307-322. http://dx.doi.org/10.7564/13-IJWG8

Kundzewicz, Z. W., N. Lugeri, R. Dankers, Y. Hirabayashi, P. Döll, I. Pińskwar, T. Dysarz, S. Hochrainer, and P. Matczak. 2010. Assessing river flood risk and adaptation in Europe-review of projections for the future. Mitigation and Adaptation Strategies for Global Change 15:641-656. http://dx.doi.org/10.1007/ s11027-010-9213-6

Larrue, C., S. Bruzzone, L. Lévy, M. Gralepois, T. Schellenberger, J. B. Trémorin, M. Fournier, C. Manson, and T. Thuilier. 2016. Analysing and evaluating flood risk governance in France: from state policy to local strategies. STAR-FLOOD Consortium, Tours, France.

Leroy, P., and B. Arts. 2006. Institutional dynamics in environmental governance. Pages 1-19 in B. Arts and P. Leroy, editors. Institutional dynamics in environmental governance. Springer, Dordrecht, The Netherlands. http://dx.doi. org/10.1007/1-4020-5079-8_1

MacKinnon, D., and K. Driscoll Derickson. 2013. From resilience to resourcefulness: a critique of resilience policy and activism. Progress in Human Geography 37(2):253-270. http://dx. doi.org/10.1177/0309132512454775 
Macnaghten, P., and M. Jacobs. 1997. Public identification with sustainable development: investigating cultural barriers to participation. Global Environmental Change 7(1):5-24. http://dx. doi.org/10.1016/s0959-3780(96)00023-4

Matczak, P., J. Lewandowski, A. Choryński, M. Szwed, and Z. Kundzewicz. 2016. Flood risk governance in Poland: looking for strategic planning in a country in transition. STAR-FLOOD Consortium, Poznan, Poland.

Mees, H. L. P., P. P. J. Driessen, and H. A. C. Runhaar. 2014. Legitimate adaptive flood risk governance beyond the dikes: the cases of Hamburg, Helsinki and Rotterdam. Regional Environmental Change 14(2):671-682. http://dx.doi.org/10.1007/ s10113-013-0527-2

Mees, H., C. Suykens, J. C. Beyers, A. Crabbé, B. Delvaux, and K. Deketelaere. 2016a. Analysing and evaluating flood risk governance in Belgium. Dealing with flood risks in an urbanised and institutionally complex country. STAR-FLOOD Consortium, University Antwerp, Leuven, Belgium.

Mees, H., B. Tempels, A. Crabbé, and L. Boelens. 2016b. Shifting public-private responsibilities in Flemish flood risk management. Towards a co-evolutionary approach. Land Use Policy 57:23-33. http://dx.doi.org/10.1016/j.landusepol.2016.05.012

Meijerink, S., and W. Dicke. 2008. Shifts in the public-private divide in flood management. International Journal of Water Resources Development 24(4):499-512. http://dx.doi. org/10.1080/07900620801921363

Mitlin, D. 2008. With and beyond the state - co-production as a route to political influence, power and transformation for grassroots organizations. Environment \& Urbanization 20 (2):339-360. http://dx.doi.org/10.1177/0956247808096117

National Flood Forum (NFF). 2016. About us: what the National Flood Forum does. NFF, Bewdley, Worcestershire, UK. [online] URL: http://www.nationalfloodforum.org.uk/about-us/

Needham, C. 2008. Realising the potential of co-production: negotiating improvements in public services. Social Policy and Society 7(2):221-231. http://dx.doi.org/10.1017/s1474746407004174

Nye, M., S. Tapsell, and C. Twigger-Ross. 2011. New social directions in UK flood risk management: moving towards flood risk citizenship? Journal of Flood Risk Management 4:288-297. http://dx.doi.org/10.1111/j.1753-318X.2011.01114.x

Organisation for Economic Co-operation and Development (OECD). 2015. Stakeholder engagement for inclusive water governance. OECD Studies on Water. OECD, Paris, France. http://dx.doi.org/10.1787/9789264231122-en

Osborne, S. P., and K. Strokosch. 2013. It takes two to tango? Understanding the co-production of public services by integrating the services management and public administration perspectives. British Journal of Management 24:S31-S47. http:// dx.doi.org/10.1111/1467-8551.12010

Ostrom, E. 1990. Governing the commons: the evolution of institutions for collective action. Cambridge University Press, Cambridge, UK. http://dx.doi.org/10.1017/CBO9780511807763
Ostrom, E. 1996. Crossing the great divide: coproduction, synergy, and development. World Development 24(6):1073-1087. http://dx.doi.org/10.1016/0305-750x(96)00023-x

Ostrom, V., C. M. Tiebout, and R. Warren. 1961. The organization of government in metropolitan areas: a theoretical inquiry. American Political Science Review 55:831-842. http://dx. doi.org/10.2307/1952530

Parks, R. B., P. C. Baker, L. Kiser, R. Oakerson, E. Ostrom, V. Ostrom, S. L. Percy, M. B. Vandivort, G. P. Whitaker, and R. Wilson. 1981. Consumers as coproducers of public services: some economic and institutional considerations. Policy Studies Journal 9(7):1001-1011. http://dx.doi.org/10.1111/j.1541-0072.1981.tb01208. $\underline{\mathrm{x}}$

Penning-Rowsell, E. C., and C. Johnson. 2015. The ebb and flow of power: British flood risk management and the politics of scale. Geoforum 62:131-142. http://dx.doi.org/10.1016/j.geoforum.2015.03.019

Peters, B. G., and J. Pierre. 2001. Developments in intergovernmental relations: towards multi-level governance. Policy \& Politics 29(2):131-135. http://dx.doi.org/10.1332/0305573012501251

Petts, J. 2007. Learning about learning: lessons from public engagement and deliberation on urban river restoration. Geographical Journal 173(4):300-311. http://dx.doi.org/10.1111/ j.1475-4959.2007.00254.x

Renn, O. 2008. Risk governance: coping with uncertainty in a complex world. Earthscan, London, UK.

Rijksoverheid. 2012. Deltaprogramma Nieuwbouw en Herstructurering en Veiligheid. Waterveiligheid buitendijks. Rijksoverheid, The Hague, The Netherlands.

Rose, N. 2000. Community, citizenship and the third way. American Behavioral Scientist 43(9):1395-1411. http://dx.doi. org/10.1177/00027640021955955

Rothstein, H., O. Borraz, and M. Huber. 2013. Risk and the limits of governance: exploring varied patterns of risk-based governance across Europe. Regulation \& Governance 7:215-235. http://dx.doi.org/10.1111/j.1748-5991.2012.01153.x

Steinführer, A., G. Delli Zotti, M. Del Zotto, B. De Marchi, A. Fernandez-Bilbao, C. Kuhlicke, A. Scolobig, S. Tapsell, and S. Tunstall. 2009. Communities at risk: vulnerability, resilience and recommendations for flood risk management: executive summary. Report No. T11-07-15. FLOODsite Consortium, European Commission, Brussels, Belgium. [online] URL: http://www. floodsite.net/html/partner_area/project_docs/T11_07_15_Vulnerability resilience ExecSum v2 2 p01.pdf

Termeer, C. J. A. M., A. Dewulf, and M. van Lieshout. 2010. Disentangling scale approaches in governance research: comparing monocentric, multilevel, and adaptive governance. Ecology and Society 15(4):29. [online] URL: http://www. ecologyandsociety.org/vol15/iss4/art29/

Thaler, T., and S. Priest. 2014. Partnership funding in flood risk management: new localism debate and policy in England. Area 46(4):418-425. http://dx.doi.org/10.1111/area.12135 
Tippett, J., B. Searle, C. Pahl-Wostl, and Y. Rees. 2005. Social learning in public participation in river basin management - early findings from HarmoniCOP European case studies. Environmental Science \& Policy 8(3):287-299. http://dx.doi.org/10.1016/j. envsci.2005.03.003

Twigger-Ross, C., P. Orr, K. Brooks, R. Sadauskis, H. Deeming, J. Fielding, T. Harries, R. Johnston, E. Kashefi, S. McCarthy, Y. Rees, and S. Tapsell. 2015. Flood Resilience Community Pathfinder evaluation: final report FD1664. Department for Environment, Food and Rural Affairs, London, UK.

Van Nes, R., H. Horsten, and K. Faddegon. 2001. Watermonitor 2001. Veiligheid en overlast, verdroging en watervervuiling. Van Nes Research Management, Bussum, The Netherlands.

Van Rijswick, H. F. M. W., and H. J. M. Havekes. 2012. European and Dutch water law. Europa Law, Groningen, The Netherlands.

Van Waarden, F. 1995. Persistence of national policy styles: a study of their institutional foundations. Pages 333-368 in B. Unger and F. van Waarden, editors. Convergence or diversity? Internationalization and economic policy response. Avebury, Aldershot, UK.

Vlaamse Milieumaatschappij (VMM). 2014. Onderbouwing van het Overstromingsrisicobeheerplan van de onbevaarbare waterlopen. ORBP-analyse Basisrapport. VMM, Erembodegem, Belgium.

Walker, B., C. S. Holling, S. R. Carpenter, and A. Kinzig. 2004. Resilience, adaptability and transformability in social-ecological systems. Ecology and Society 9(2):5. [online] URL: http://www. ecologyandsociety.org/vo19/iss2/art5/

Watson, V. 2014. Co-production and collaboration in planningthe difference. Planning Theory \& Practice 15(1):62-76. http://dx. doi.org/10.1080/14649357.2013.866266

Watson, N., H. Deeming, and R. Treffny. 2009. Beyond bureaucracy? Assessing institutional change in the governance of water in England. Water Alternatives 2(3):448-460.

Whitaker, G. P. 1980. Coproduction: citizen participation in service delivery. Public Administration Review 40(3):240-246. http://dx.doi.org/10.2307/975377

White, I., R. Kingston, and A. Barker. 2010. Participatory geographic information systems and public engagement within flood risk management. Journal of Flood Risk Management 3 (4):337-346. http://dx.doi.org/10.1111/j.1753-318x.2010.01083.x

Wielinga, A., R. Idema, J. Zwinkels, E. Regterschot, C. Grootscholten, B. Muskens, W. Porton, A. Boxman, R. Bruinsma, I. van Oorschot, C. Overgoor, P. Mul, E. Delhez, I. Keuning, R. Vader, M. Oosterbaan, L. Holtmaat, P. Lamberigts, and J. Langeveld. 2015. Gemeentelijke Barometer Fysieke Leefomgeving. Vereniging van Nederlandse Gemeenten and Royal HaskoningDHV, The Hague, The Netherlands.

Wiering, M., C. Green, M. van Rijswick, S. Priest, and A. Keessen. 2015. The rationales of resilience in English and Dutch flood risk policies. Journal of Water and Climate Change 6(1):38-54. http:// dx.doi.org/10.2166/wcc.2014.017 
Appendix 1. Non-exhaustive list of questions asked in the STAR-FLOOD interviews

This appendix provides a non-exhaustive list of examples of questions asked on the topic of citizen involvement in FRM during the semi-structured interviews. These questions were embedded in a general conversation on flood risk governance, which discussed the role of actors, rules, resources and discourses, and important trends of change. The interviews have been conducted in the mother tongue of the respondents.

Examples of questions asked to public officials in crisis management:

[? Which actions do people take themselves against flooding?

? Do emergency services make use of volunteering citizens during flood events?

o Is it stimulated by the emergency services?

o Do they make a significant contribution to the formal emergency response?

o How is this volunteering initiated? Is it organised prior to the event?

[? Do you see any evolution in this? Do people take more actions themselves than in the past? Are there more volunteers?

[. Are citizens involved in the draft of flood emergency plans? Can they actively participate in vulnerability assessment?

? How are issues of accountability and insurance dealt with?

Examples of questions asked to public officials in water management:

? What is the role of citizens in flood risk management?

? Is it expected that citizens take individual measures against flood risks? Do they share responsibility in addressing flood risks?

o If yes, is this actively communicated?

? Are individual precautionary measures in a way stimulated, e.g. though subsidies, expertise, etc.?

? Are citizens willing to take own measures? Are they prepared to take on responsibility?

?] Are there citizen groups actively dealing with floods in this area? What kind of relation do you have with them?

? How are citizens involved in the development of new flood risk policy? And NGOs? Can they actively participate in the decision-making process?

Examples of questions asked to civil actors (NGOs, neighbourhood groups, etc.):

? Which role do citizens play in the management of flood risks?

? Do you think you are sufficiently involved by authorities in the development of flood risk management?

o If not, how would you like to become more involved?

? Would you be interested to participate in emergency planning concerning flooding, e.g. draft emergency plans at neighbourhood level?

? Do people in the neighbourhood take own measures to prepare for flooding, and protect their house from flooding? Do you consider this the role of citizens as well?

? Did people help each other during and after the flood? In which way?

[. Are citizens supported by authorities to take flood risk actions, e.g. subsidies, material support, expertise,...?

[? Do you have sufficient access to the decision-making process? 